\title{
Increased angiotensin-converting enzyme activities in diabetes mellitus: analysis of diabetes type, state of metabolic control and occurrence of diabetic vascular disease* $^{*}$
}

\author{
G SCHERNTHANER, CH SCHWARZER, R KUZMITS, MM MÜLLER, U KLEMEN, \\ H FREYLER
}

From the Department of Medicine II, Department of Cardiology, Department of Surgery II, Department of Ophthalmology I, University of Vienna, Austria, and the Ludwig Boltzmann-Institute for Clinical Endocrinology, Vienna, Austria

SUMMARY Serum angiotensin-converting enzyme activities were measured in 41 type 1 diabetics $(16.4 \pm 4.0 \mathrm{U} / \mathrm{ml})$, in 40 type 2 diabetics $(15.0 \pm 5.2 \mathrm{U} / \mathrm{ml})$ and in 52 controls $(13.0 \pm 2.7 \mathrm{U} / \mathrm{ml}$, mean \pm SD). Twenty six $(32 \%)$ of 81 patients presented with serum angiotensin-converting enzyme activities above the normal range. No relation between serum angiotensin-converting enzyme activities and the presence or lack of diabetic vascular diseases in type 1 and type 2 diabetics could be detected. No significant differences in serum angiotensin-converting enzyme activities were found when comparing various types of diabetic vascular disease (retinopathy, neuropathy, renal failure, arterial vascular disease, diabetic vascular disease, coronary artery disease). However, mean serum angiotensin-converting enzyme activities were significantly increased in diabetics with retinopathy when compared with controls $(p<0.0005)$. Correlation between metabolic long term control as determined by measuring glycohaemoglobin $\left(\mathrm{HbA}_{1}\right)$ concentrations and serum angiotensin-converting enzyme activities could not be established. Serum angiotensin-converting enzyme activities did not show any correlations with duration of diabetes, age or sex of patients.

A representative number of diabetics $(32 \%)$ showed elevated serum angiotensin-converting enzyme activities, but a correlation with diabetic vascular disease, metabolic control or type of disease could not be established.

In 1975 Lieberman' discovered the association between active sarcoidosis and raised serum angiotensin-converting enzyme activities. Consecutive studies confirmed ${ }^{2-5}$ the usefulness of serum angiotensin-converting enzyme determination in diagnosis and follow up of sarcoidosis.

In 1980 a possible relation between raised serum angiotensin-converting enzyme activities and diabetes mellitus was reported, ${ }^{6}$ especially in the investigation of diabetic retinopathy patients. The association between raised serum angiotensin-converting enzyme activity and diabetic microangiopathy could

*Presented in part at the XIV Acta Endocrinologica Congress, Stockholm, 27-30 June 1983.

Accepted for publication 23 November 1983 possibly offer an additional diagnostic tool in monitoring diabetic patients. However, in Lieberman's study important factors such as type of diabetes, state of metabolic long term control and form of treatment were not taken into consideration, when patients with or without vascular complications were evaluated. Therefore, a more extensive investigation of serum angiotensin-converting enzyme was undertaken in diabetes mellitus patients, well defined according to (a) type of diabetes mellitus; (b) presence or lack of diabetic vascular disease; (c) method of treatment; and (d) state of metabolic long term control. We also examined the relation between serum angiotensin-converting enzyme and glycohaemoglobin $\left(\mathrm{HbA}_{1}\right)$ concentrations in diabetics before as well as after intensified therapy. 


\section{Patients and methods}

This study was performed on 133 subjects, comprising 41 patients with type 1 (juvenile onset, insulin dependent) diabetes, 40 patients with type 2 (maturity onset, non-insulin dependent) diabetes and 52 normotensive controls without past history of pulmonary, liver, or thyroid disease. The clinical data of the patients and controls are shown in the Table. In patients with diabetic vascular disease (groups A and $C)$ the mean age was somewhat higher and the duration of the disease significantly longer $(p<$ $0.001)$ than in those without vascular tissue damage (groups B and D). All of the 41 type 1 diabetics were treated with insulin injections twice daily as well as diet. Twenty nine of the $\mathbf{4 0}$ type 2 diabetics were on insulin at the time of the study, however were previously treated with oral hypoglycaemic agents and diet. Only five type 2 diabetics were still on oral hypoglycaemic agents at the time of investigation.

Blood was drawn by venepuncture in the fasting state. In the diabetics blood samples were taken on the first day of admission to hospital and again after 10 to 60 days of intensified diabetes treatment.

Serum angiotensin-converting enzyme activities were determined spectrophotometrically according to the method of Cushman and Cheung' in the modification of Lieberman,' using hippuryl-L-histidyl-Lleucine as substrate. The substrate was purchased from Bachem Feinchemikalien, Bubendorf, Switzerland. Serum angiotensin-converting enzyme was measured in duplicate; results are reported as $\mathrm{U} / \mathrm{ml}$ (nanomoles of hippuric acid liberated per minute per $\mathrm{ml}$ serum). The intra-assay variance was less than $5 \%$ and the interassay variance was less than $6 \%$.

Glycohaemoglobin $\left(\mathrm{HbA}_{1}\right)$ concentrations were measured by microcolumn chromatography according to Welch and Boucher. ${ }^{8}$

\section{Results}

The mean ( \pm SD) serum angiotensin-converting enzyme activity in healthy controls was $13 \cdot 0 \pm 2 \cdot 7$ $\mathrm{U} / \mathrm{ml}$. The upper limit of the normal range (mean \pm $2 \mathrm{SD})$ was taken as $18.4 \mathrm{U} / \mathrm{ml}$. Fig. 1 shows the angiotensin-converting enzyme activities of the diabetic patients according to the type of disease and the presence or absence of diabetic vascular disease. There was a wide overlap in serum angiotensinconverting enzyme levels between diabetic patients and controls. However, $26(32 \%)$ of 81 patients had serum angiotensin-converting enzyme activities above the normal range. Serum angiotensinconverting enzyme activities did not show any correlation with the duration of disease, age or sex of the patients. The number of patients with raised serum angiotensin-converting enzyme activities was similar in type 1 diabetics with $(5 / 20 ; 25 \%)$ or without diabetic vascular disease $(6 / 21 ; 29 \%)$. Six of 14 (43\%) type 2 diabetics without diabetic vascular disease had increased angiotensin-converting enzyme levels.

The mean angiotensin-converting enzyme activities did not significantly differ in groups of patients with different types of diabetic vascular disease (Fig. 2). However, the highest mean angiotensin-converting enzyme activities were found in patients with diabetic retinopathy. Compared with the control group, only the aforementioned group showed significantly higher angiotensin-converting enzyme activities $(p<0.0005)$. Nevertheless, 18 of 24 diabetic retinopathy patients showed angiotensin-converting enzyme activities within the normal range.

Angiotensin-converting enzyme activities and $\mathrm{HbA}_{1}$ concentrations were measured simultaneously in all 81 patients at the onset of the study. In 45 patients determination of angiotensin-converting enzyme was repeated after intensified therapy. The

Clinical findings of the diabetic patients and controls

\begin{tabular}{|c|c|c|c|c|c|c|c|c|c|c|c|c|c|c|}
\hline & & \multirow{2}{*}{$\begin{array}{l}\text { Age }(y r) \\
(\text { mean } \pm S D)\end{array}$} & \multirow{2}{*}{$\frac{\operatorname{Sex}}{M}$} & \multirow[b]{2}{*}{$F$} & \multirow{2}{*}{$\begin{array}{l}\text { Duration } \\
\text { of disease (yr) }\end{array}$} & \multirow{2}{*}{$\begin{array}{l}H b A_{1} \\
(\text { rel \%) }\end{array}$} & \multicolumn{5}{|c|}{ Complications } & \multicolumn{3}{|c|}{ Therapy } \\
\hline & & & & & & & $\bar{R}$ & $N$ & $R f$ & $C A D$ & $\overline{A V D}$ & $\begin{array}{l}\text { Insulin } \\
+ \text { diet }\end{array}$ & $\begin{array}{l}\text { Glib } \\
+ \text { diet }\end{array}$ & $\overline{\text { Diet }}$ \\
\hline \multicolumn{2}{|r|}{$\begin{array}{l}\text { Type } 1 \text { with DVB } \\
(\mathrm{n}=20)\end{array}$} & $35.9 \pm 14 a$ & 11 & 9 & $17 \cdot 5 \pm 9$ & $11 \cdot 0 \pm 2 \cdot 5$ & 15 & 3 & 4 & 2 & 4 & 20 & - & - \\
\hline B & $\begin{array}{l}\text { Type } 1 \text { without DVD } \\
(\mathrm{n}=21)\end{array}$ & $27 \cdot 3 \pm 12 a$ & 12 & 9 & $8 \cdot 2 \pm 9$ & $11 \cdot 1 \pm 2 \cdot 7$ & - & - & - & - & - & 21 & - & - \\
\hline C & $\begin{array}{l}\text { Type } 2 \text { with DVD } \\
(n=26)\end{array}$ & $64 \cdot 3 \pm 12 a$ & 10 & 16 & $14 \cdot 5 \pm 7$ & $12 \cdot 4 \pm 2 \cdot 9$ & 9 & 6 & 9 & 9 & 15 & 22 & 3 & 1 \\
\hline \multirow[t]{2}{*}{ D } & $\begin{array}{l}\text { Type } 2 \text { without DVD } \\
(\mathrm{n}=14)\end{array}$ & $59 \cdot 8 \pm 13 a$ & 9 & 5 & $6 \cdot 4 \pm 5$ & $10 \cdot 2 \pm 2 \cdot 5$ & - & - & - & - & - & 7 & 2 & 5 \\
\hline & Controls $(n=52)$ & $33 \cdot 3 \pm 11 \cdot 3 a$ & 21 & 31 & - & $6 \cdot 3 \pm 0.7$ & & & & & & & & \\
\hline
\end{tabular}

$R=$ retinopathy. $N=$ neuropathy. $R f=$ renal failure. $C A D=$ coronary artery disease. $A V D=$ arterial vascular disease. $D V D=$ diabetic vascular disease. 


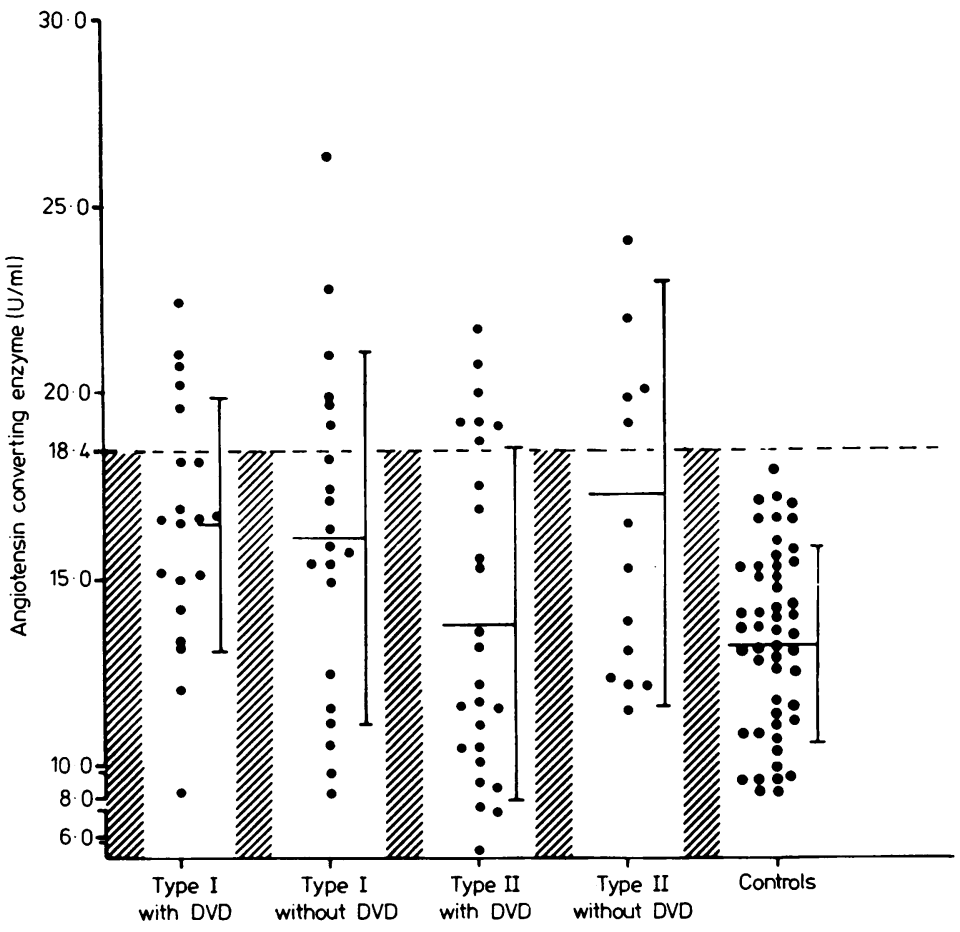

Fig. 1 Serum angiotensin-converting enzyme activities in diabetic patients (type 1 and type 2 diabetes mellitus) with or without diabetic vascular disease (DVD).

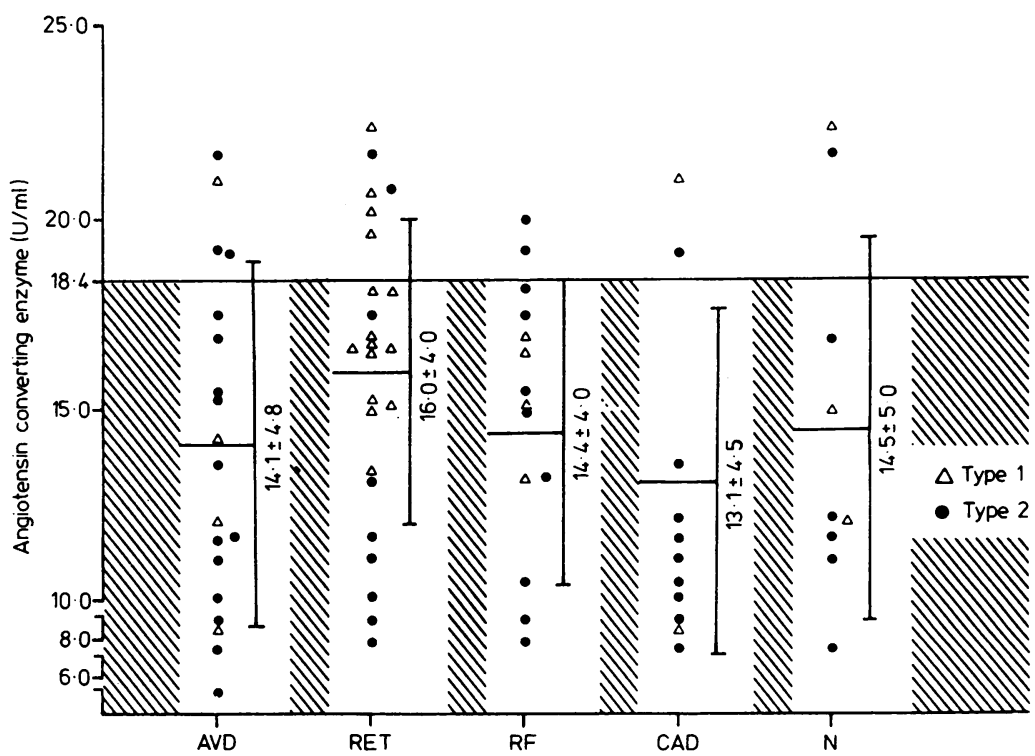

Fig. 2 Serum angiotensin-converting enzyme activities in patients with different types of diabetic vascular disease. $\triangle$ type 1 diabetes mellitus, $\bullet$ type 2 diabetes mellitus, $A V D$ : arterial vascular disease, RET: retinopathy, $R F$ : renal failure, CAD: coronary artery disease, $N$ : neuropathy. 
interval between the two investigations was $10-60$ days. In 11 patients increased serum angiotensinconverting enzyme activities were found at both investigations. No correlation between the metabolic long term control $\left(\mathrm{HbA}_{1}\right)$ and serum angiotensin-converting enzyme activities could be detected. Angiotensin-converting enzyme activities were quite similar irrespective of whether patients showed excellent $\left(\mathrm{HbA}_{1}<9.0 \%\right.$; angiotensinconverting enzyme $16 \cdot 8 \pm 5.6 \mathrm{U} / \mathrm{ml})$, fair $\left(\mathrm{HbA}_{1} 9 \cdot 1\right.$ $-10 \cdot 2 \%$; angiotensin-converting enzyme $15 \cdot 8 \pm$ $5.0 \mathrm{U} / \mathrm{ml})$, moderate $\left(\mathrm{HbA}_{1} \quad 10 \cdot 3-12.0 \%\right.$; angiotensin-converting enzyme $15.3 \pm 5.0 \mathrm{U} / \mathrm{ml}$ ) or poor $\left(\mathrm{HbA}_{1}>12 \%\right.$; angiotensin-converting enzyme $16 \cdot 8 \pm 4 \cdot 1 \mathrm{U} / \mathrm{ml})$ metabolic control. The intraindividual changes of angiotensin-converting enzyme and $\mathrm{HbA}_{1}$ of 10 diabetics from the state of poor diabetes control to improved metabolic control after two months are shown in Fig. 3. Although $\mathrm{HbA}_{1}$ concentrations decreased in all patients, angiotensin-converting enzyme showed a rise in six of them and remained unchanged in two.

\section{Discussion}

Lieberman $^{6}$ reported sporadic or persistent raised activity of serum angiotensin-converting enzyme in $24 \%$ of diabetes mellitus patients. In that study ${ }^{6}$ the incidence of retinopathy was higher in patients with raised angiotensin-converting enzyme activities than

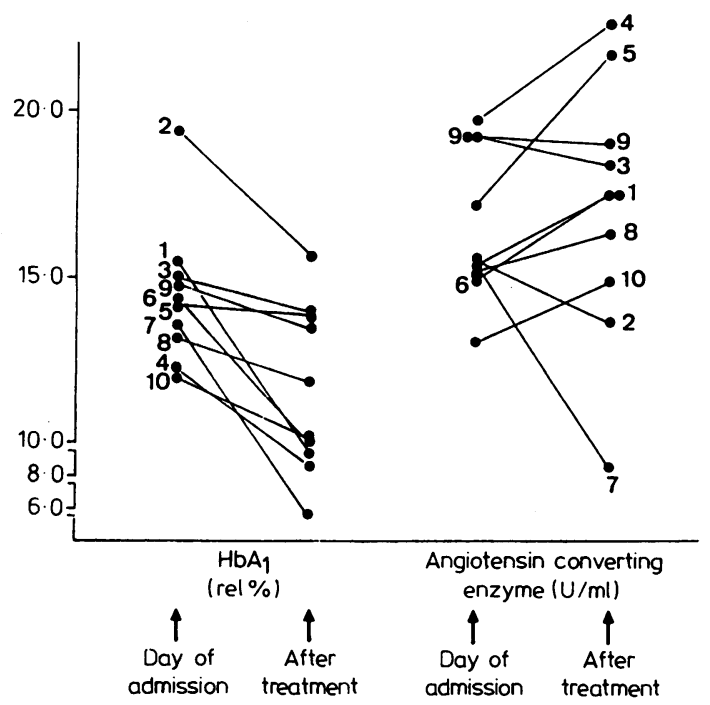

Fig. 3 Changes in $\mathrm{Hb} \mathrm{A}_{1}$ concentrations and serum angiotensin-converting enzyme activities in diabetic patients following intensified therapy. in diabetics with normal angiotensin-converting enzyme activities (48\% $v 20 \%)$. Remarkably, 37 of 64 patients with diabetic retinopathy and seven of 14 patients with diabetic nephropathy showed normal angiotensin-converting enzyme activities. Lieberman speculated ${ }^{6}$ that diffuse vascular damage could have released the enzyme into the blood stream.

In the present study significant association between the presence of late diabetic complications and raised angiotensin-converting enzyme activity could not be found. However, $32 \%$ of all diabetics showed sporadic raised activities in serum angiotensin-converting enzyme and $14 \%$ presented persistent raised serum angiotensin-converting enzyme, confirming the report of Lieberman ${ }^{6}$ that a representative number of diabetics show raised angiotensin-converting enzyme. The absence of raised angiotensin-converting enzyme in a large number of patients with overt diabetic retinopathy or diabetic nephropathy, or both, demonstrated in the present study is an important argument against the intriguing concept that systemic diabetic microangiopathy leads to an increase in serum angiotensin-converting enzyme activity. In a number of reports ${ }^{9-12}$ a correlation between late diabetic complications and insufficient diabetes control in the history of patients has been noted. Interestingly, metabolic long term control; evaluated by stable $\mathrm{HbA}_{1}$ concentrations, did not show any correlation with serum angiotensin-converting enzyme activity in this investigation.

Thus, the precise underlying mechanism for the increased serum angiotensin-converting enzyme activities in $20-40 \%$ of diabetics remains to be clarified. In this connection it seems noteworthy that raised angiotensin-converting enzyme activities have been noted in $90 \%$ of patients with hyperthyroidism, ${ }^{13}{ }^{14}$ suggesting that endocrinological factors may also be related to an increase in serum angiotensin-converting enzyme activity. Beside sarcoidosis $^{1}$ a variety of diseases-for example, Gaucher's disease,,$^{15}$ leprosy, ${ }^{16}$ silicosis and asbestosis, ${ }^{17}$ chronic renal failure requiring haemodialysis, ${ }^{18}$ acute and chronic diseases of the liver, ${ }^{18-20}$ hyperthyroidism ${ }^{1314}$ and diabetes mellitus ${ }^{6}$-are now identified as being associated with increased serum angiotensin-converting enzyme activity. It seems likely that different factors contribute to increased angiotensin-converting enzyme serum activities in such heterogenous disorders.

Regarding diabetes mellitus, a subclinical disturbed liver function could have influenced serum angiotensin-converting enzyme activity, although liver function tests of the diabetic patients were within the normal range and did not correlate with 
angiotensin-converting enzyme activity. It cannot be excluded that the liver may inactivate serum angiotensin-converting enzyme; hence, impaired hepatic clearance may increase serum angiotensinconverting enzyme activity in disorders such as diabetes mellitus associated with subclinical disturbances of the liver.

A variety of insulins and insulin fragments were shown to be active as inhibitors of serum angiotensin-converting enzyme in vitro. ${ }^{21}$ Igic et al ${ }^{22}$ demonstrated the inhibitory effect of insulin on purified angiotensin-converting enzyme from hog lung, and insulin also blocked the action of angiotensin-converting enzyme in lung perfusion experiments in rat lung in situ. Serum insulin or $C$ peptide concentrations were not measured in our patients, but the possibility cannot be excluded that insulin deficiencies in plasma or tissue might contribute to raised serum angiotensin-converting enzyme activities. Interestingly, type 1 diabetics with retinopathy demonstrated considerably higher angiotensin-converting enzyme activities (17.6 \pm $2.5 \mathrm{U} / \mathrm{ml}$ ) than type 2 diabetics with the corresponding microvascular retinal lesions $(14 \cdot 1 \pm 5 \cdot 8 \mathrm{U} / \mathrm{ml})$. In addition, four patients with type 1 diabetes and proliferative retinopathy showed serum angiotensin-converting enzyme activities of $17.4 \pm$ $2.5 \mathrm{U} / \mathrm{ml}$ whereas in three type 2 diabetics with proliferative retinopathy serum angiotensin-converting enzyme activities of only $9.6 \pm 1.9 \mathrm{U} / \mathrm{ml}$ could be measured (the other patients with diabetic retinopathy presented either background retinopathy or preretinopathy and did not show any differences between type 1 or type 2 diabetics).

Increased serum angiotensin-converting enzyme activities were found in hypertensive patients by one group, ${ }^{23}$ findings which -were not confirmed in another study. ${ }^{24}$ In the present investigation hypertension was found in only eight of the 30 diabetics (one type 1 diabetes, seven type 2 diabetes) with increased serum angiotensin-converting enzyme activities. Thus, it seems unlikely that in diabetics hypertension plays a major role in the raising of serum angiotensin-converting enzyme activity.

The mechanisms for raised activity in serum angiotensin-converting enzyme in about one third of diabetics remains at present unclear. However, our study definitely shows that increased angiotensinconverting enzyme activity cannot be taken as a marker for generalised tissue damage or extensive vascularisation, because (a) angiotensin-converting enzyme activities were increased in only some of the diabetics with microangiopathy and (b) patients with short diabetes duration $(<5 \mathrm{yr})$ showed similar or even higher angiotensin-converting enzyme activities than patients with longstanding diabetes.
This is a strong argument against the hypothesis that even subclinical diabetic vascular injury may raise serum angiotensin-converting enzyme, because the outcome of late diabetic vascular complications correlates strongly with the duration of disease..$^{25}$

Although the mechanism responsible for the increase in serum angiotensin-converting enzyme activity in diabetes mellitus remains to be clarified, diabetes should be taken into consideration when raised angiotensin-converting enzyme activities are to be used to confirm the diagnosis of sarcoidosis.

\section{References}

' Lieberman J. Elevation of serum angiotensin converting enzyme (ACE) level in sarcoidosis. Am J Med 1975;59:356-72.

${ }^{2}$ Studdy P, Bird R, James DG, Sherlock S. Serum angiotensin converting enzyme (SACE) in sarcoidosis and other granulomatous disorders. Lancet 1978;ii: 1331.

${ }^{3}$ Shultz T, Miller WC, Bedrossian CWM. Clinical application of measurement of angiotensin converting enzyme level. JAMA 1979;242:439-41.

${ }^{4}$ DeRemee R, Rohrbach MS. Serum angiotensin-converting enzyme activity in evaluating the clinical course of sarcoidosis. Ann Intern Med 1980;92:361-5.

${ }^{5}$ Ferlitsch A, Kummer F, Müller MM, Legenstein E, Haber P, Kohoutt J. Angiotensin converting enzyme (ACE). Ein in vitro Test für die Sarcoidose Diagnostik. Klin Wochenschr 1980;58: 195-8.

- Lieberman J, Sastre A. Serum angiotensin converting enzyme: Elevations in diabetes mellitus. Arch Intern Med 1980; 93:825-6.

' Cushman DW, Cheung HS. Spectrophotometric assay and properties of the angiotensin converting enzyme of rabbit lung. Biochem Pharmacol 1978;20:1637-48.

" Welch SG, Boucher BJ. A micro-scale method for the measurements of haemoglobin $A_{1}(a+b+c)$. Diabetologia 1978;14: 209-11.

'Job D, Eschwege E, Guyot-Argenton C, Aubry JP, Tchobroutsky $G$. Effect of multiple daily insulin injections in the course of diabetic retinopathy. Diabetes 1976;25:463-9.

${ }^{10}$ Eschwege E, Job D, Guyot-Argenton C, Aubry JP, Tchobroutsky G. Delayed progression of diabetic retinopathy by divided insulin administration: a further follow-up. Diabetologia 1978;16:13-5.

"Tchobroutsky G. Relation of diabetic control to development of microvascular complications. Diabetologia 1978;15:143-52.

12 Pirart J. Diabetes mellitus and its degenerative complications: a study of 4,400 patients observed between 1947 and 1973 . Diabetes Care 1978;1:168-88, 252-63.

${ }^{13}$ Nakamura $\mathrm{Y}$, Takeda T, Ishii $\mathrm{M}$, et al. Elevation of serum angiotensin converting enzyme. Activity in patients with hyperthyroidism. J Clin Endocrinol Metab 1982;55,5:931-4.

14 Yotsumoto H, Imai Y, Kuzuya N, Uchimura H, Matsuzaki F. Increased levels of serum angiotensin-converting enzyme activity in hyperthyroidism. Ann Intern Med 1982;96:326-8.

is Lieberman J, Beutler E. Elevation of serum angiotensin converting enzyme in Gaucher's disease. N Engl J Med 1976; 294: $1442-4$.

${ }^{16}$ Lieberman J, Rea TH. Serum angiotensin converting enzyme in leprosy and coccidioidomycosis. Ann Intern Med 1977; 87:422-5.

${ }^{17}$ Grönhagen-Riska C, Kurppa K, Fyhridquist F, Selroos O. Angiotensin converting enzyme and lysozyme in silicosis and asbestosis. Scand J Respir Dis 1978;59:228-31. 
1* Schweisfurth $\mathrm{H}$, Wernze $\mathrm{H}$. Changes of serum angiotensin 1 converting enzyme in patients with viral hepatitis and liver cirrhosis. Acta Hepato-gastroenterol 1979;26:207-10.

${ }^{19}$ Borowsky SA, Lieberman J, Strome S, Sastre A. Elevation of serum angiotensin converting enzyme level-occurrence in alcoholic liver disease. Arch Intern Med 1982;142:893-5.

${ }^{20}$ Matsuki K, Sakata T. Angiotensin-converting enzyme in diseases of the liver. Am J Med 1982;73:549-51.

${ }^{21}$ Bing J, Poulsen K; Markussen J. The ability of various insulins and insulin fragments to inhibit the angiotensin I converting enzyme. Acta Pathol Microbiol Scand [A] 1974;82:777-82.

${ }^{22}$ Igic R, Erdös EG, Yeh HSJ, Serrels K, Nakajima T. Angiotensin I converting enzyme of the lung. Circ Res 1972;31 suppl II: 51-61.

${ }^{23}$ Overlack A, Higuchi M, Kolloch R, Stumpe KO. Converting enzyme activity and essential hypertension. Klin Wochenschr 1983;61:377-8.

${ }^{24}$ Burghardt W, Schweisfurth W. Changes of angiotensinconverting enzyme (ACE) in hepatic cirrhosis: relation to the renin-angiotensin-aldosterone system (RAAS), heart rate, and blood pressure. Acta Endocrinol 1983;102 suppl 253:9.

${ }^{25}$ Lestradet H, Papoz L, Hellquin CL, et al. Long-term study of mortality and vascular complications in juvenile-onset (type I) diabetes. Diabetes 1981;30:175-9.

Requests for reprints to: Dr G Schernthaner, Department of Medicine II, University of Vienna, Garnisongasse 13, A-1090 Vienna, Austria 